\title{
DEVELOPMENT OF THE THEORY OF INNOVATIONS IN THE CONTEXT OF THE NEW INDUSTRIAL REVOLUTION
}

\author{
Elena Dovgal \\ D. Sc. (Economics), Professor \\ V.N. Karazin Kharkiv National University \\ Svobody sq., 4, Kharkiv, Ukraine, 61022 \\ e-mail: e.dovgal@karazin.ua \\ ORCID: https://orcid.org/0000-0003-3219-9731 \\ Liliia Makhova \\ Postgraduate \\ V.N. Karazin Kharkiv National University \\ Svobody sq., 4, Kharkiv, Ukraine, 61022 \\ makhova@karazin.ua
}

\begin{abstract}
The relevance of the study is due to the fact that increase of proportion of high technology production in the aggregate product of the world economy, as a consequence of the new industrial evolution mid XX-early XXI century, defines a completely new, in terms of world experience, range of system views on the global economic system. The subject of research of the article is a process of developing of the theory of innovation system, an analysis of impact of the theory of long wave cycles on the innovative development of society. The goal of the article is to analyze the development of the theory of global and national innovative high-tech systems in time, considering the hypothesis of the existence of a rigid connection between long waves and the periods of basic innovation occurrence at various phases of the waves, in order to recognize the possible options for the development of events and to model the appropriate reaction to ensure the uninterrupted functioning of the national innovation system in the context of the new industrial revolution. The objective is to research the patterns of the life cycle of innovations and their diffusion to identify the advantages and disadvantages of a transfer of high technology products for the national innovation system and also to identify the development trends and new factors, which define the essence of modern efficient high-tech system in terms of the new industrial revolution. General scientific methods are used, such as system analysis - to determine the patterns of the life cycle of innovations and their diffusion to identify the advantages and disadvantages of a transfer of high technology products for the national innovation system, factor analysis - toformalizethecause-andeffectrelationshipsoftheinvestigatedfactorsof the development of modern effective high-tech system. The following results were obtained: on the basis of the analysis of the impact of the long waves theory on the innovative development of society is proved the necessity of the fastest access of domestic enterprises to world network markets not only to develop the sales network, but also to search for innovative solutions and creative interactions. These practices are suitable for most countries, which have adopted the experience of world's innovative leaders and now are competitive players of the world market of high technologies. Conclusions: the urgency to create a strong national innovation system in Ukraine, considering the specificity of those elements that are now the basis of functioning of innovative systems.

Keywords: innovation, innovation development, global challenges, national competitiveness, innovative potential, new industrial revolution.
\end{abstract}

\section{Introduction.}

The significant increase of proportion of high technology production in the aggregate product of the world economy, as a consequence of the new industrial evolution mid XX-early XXI century, defines a completely new, in terms of world experience, range of system views on the global economic system. Updating of implements, methods of production and improving the level of qualification characteristics of an aggregate worker, goes far beyond the simple renovation of physical capital, increase the efficiency of production and productivity, capital, etc.

The high rates of reconfiguration of the main parameters of productive forces, market "rules of the game" and growth of value of economic relations in the intellectual property sphere, indicates a natural transformation of rare innovations that took place in the past, into a complete differentiated global innovation system. The socio-economic welfare of any modern economy depends on the business activity of national agents in this system, especially in the context of high-tech product commercialization.

Therefore, the purpose of the research is a sequential analysis of innovative concepts and stages of formation of the principles of functioning of global and national innovation systems for the purpose of country`s further participation in the international division of labor, namely effective high-tech product commercialization.

Literature review and problem statement.

D. Breznitz [2], C. Freeman [5-6], J. Kao [7], M. Kastels [8], A. Kleinkneht [9], G. Mensh [10-12], J. Schumpeter [15], J. Van Duijn [16] and others have dedicated their works to the research of national innovation systems functioning principles in terms of world global development.

Despite numerous researches of innovative hightech systems' economic nature, there are significant differences in views of different scientific schools, in particular on their factors that shape the system, namely the lifecycle of innovations, i.e. stage of their occurrence in the period of long wave, which causes large-scale discussions on propensity for investment and an importance of investment risk factor, economic relations in the network economy, etc.

These disagreements slow down and sometimes make it impossible the process of forming a slender theoretical base for building integrated models of 
national innovation systems and their interaction in the context of the new industrial revolution.

The aim of the study is to analyze the development of the theory of global and national innovative high-tech systems in time, considering the hypothesis of the existence of a rigid connection between long waves and the periods of basic innovation occurrence at various phases of the waves, in order to recognize the possible options for the development of events and to model the appropriate reaction to ensure the uninterrupted functioning of the national innovation system in the context of the new industrial revolution.

Substantial statement of the problem.

Another important assignment of the study is to research the patterns of the life cycle of innovations and their diffusion to identify the advantages and disadvantages of a transfer of high technology products for the national innovation system and also to identify the development trends and new factors, which define the essence of modern efficient high-tech system in terms of the new industrial revolution.

Qualitative socio-economic transformations and the modern multi-dimensional innovation system formation and recognition of innovations as one of the main tools for meeting the needs of society is directly dependent on the scientific and technological progress which caused these changes. The emergence of new base (which significantly intensifying the production process) inventions is a qualitatively new stage of social development, it also generates new needs and renewed production changes, which is responsible for it.

The term "technical progress" was put into circulation in the XX century, in the context of the substantiation of the traditional scientific and engineering picture of the world, which characterizes the interconnected and mutually stimulating development of science and technology.

The goal of technological progress is to meet the ever-growing human needs, and to meet these needs with the implementation of natural sciences and equipment. At the same time, the prerequisite stage of a slow and independent development of science and technology, and the stage of scientific and technical revolutions are different.

According to the researchers, there were three industrial revolutions in the past, and now the world community is experiencing the fourth one.

Industrial revolution is a transition to a qualitatively new level of equipment and technology, leading to a sharp increase in productivity and production.

The First Industrial revolution occurred in different countries not at the same time, but in general is assumed, that it began in the second half of the XVIII century and lasted till the beginning of the XIX century and was associated with the invention of weaving machines.

The first industrial revolution led to replacement of human hands in almost all areas of production and caused a colossal rise in labor productivity on the basis of the large machine industry. Since the first industrial revolution, the term technology is inextricably linked with the mechanization of production processes.

The Second Industrial Revolution (it is also called technological) is a transformation in the world industry, covering the second half of the XIX century and the beginning of the XX century. The beginning of the revolution is connected with the introduction of The Bessemer process -the first inexpensive and highperformance method of industrial production of fine steel in the 1860-90s. The peak of this revolution was introduction and distribution of conveyor belt production and production lines. In 1860-1870s technological revolution quickly covered Western Europe, USA, Russian Empire and Japan.

The Third Industrial Revolution was accompanied by automation, robotics and computerization of production, the creation of automatic factories. It is usually denoted as "digital revolution" - a widespread transition to the usage of information and communication technologies in production, which contributed to the formation of postindustrial society. It continues now on in major industries.

Despite the fact that the concept of the third industrial revolution at the beginning of the XXI century has not yet been sustainable, there is already an idea of The Fourth Industrial Revolution. German privately-state program Industrie 4.0 is associated with the term. Large German concerns, supported by the Federal government grants, within the framework of the program, create fully automated production, lines and products that interact with each other and consumers, due to CPS, in the factory processes [1]. CPS is a comprehensive term that is widely used in everyday life, when it comes to integrating small Internet connected devices and mechanical systems. Executives of enterprises do not just reassess the principle of conveyor assembly technology, but also actively create hybrid technological systems that will not only produce goods with fewer errors, but also be able to independently change the production templates, remaining highly effective.

In other words, the Industrie 4.0 is the production side, equivalent to user-friendly "Internet of Things", where household items, such as cars and toasters, will be connected to the Internet and managed by artificial intelligence [3].

Obviously, all of industrial revolutions had innovations as driving forces. Innovation economics has also come a long way of development.

J. Schumpeter, Austrian political economist, is considered as a founder of Innovation economics, he investigated long-term Kondratiev waves and linked them with the evolution of science. The patterns of interdependence of science and economic activity dynamics, determined by Schumpeter, were called the Theory of innovative cycles (business cycles).

J. Schumpeter built his theory on the basis of numerous observations of $M$. Kondratiev for the dynamics of economic conjuncture, thathe connected with ascending phases of Kondratiev long wave with a mass introduction of innovations.

According to Schumpeter, the clusters of innovations cause the destruction of investment demand in modernized basic capital on the ascending phase of the long waves, causing a radical trans 
formation in the economy and destabilize it, when no recovery is expected; a new cycle will be gin with the downard phase (the depressions tage) of a large wave, but at a different point of equilibrium, different from the previous one.

Innovations disturb the economic system, unbalance it and brings an element of unpredictability, increase the vibrations, causing a "rocking swing" (accurate explanation of circularity of P. Samuelson), at the same time making a path to a qualitatively new stage of the system development.

This process the scientist characterized as a creative destruction, because with the introduction of many innovations, parameters of the system and its main structural elements are modified -economic relations and productive forces, irrelevant and outdated connections and components are reestablished.

Schumpeter suggested a classifying model of business cycles, combining short, medium and longterm cycles of Kitchin, Juglar and Kondratiev together to form a single model of innovative cycles. According to the scientist, radical inventions make the main impetus for the spread of each wave, which greatly influenced the further development of society and formed a new vision of economic configuration of the economy [14].

Radical innovations, designed to carry out a technological coup, by J. Schumpeter, arise in the previous cycle, it means, that the discovery comes significantly earlier, then the stage of its mass consumption, which eventually leads to a decline stage. This feature is explained by inertia in making decisions by the owners of capital, management and state functionality, high risk of investment projects and stereotype thinking of agents: the main motive of a firm is to maximize profits and reduce costs.

An innovative breakthrough takes place in selected countries and industries, with higher risk readily, which causes disproportion of social reproduction. Over time, other entrepreneurs, realizing the success of implemented projects with a high norm of profits, begin to "catch up" competitors in the pursuit of a high norm of profit;as follows, on the market of goods there is a huge number of improving innovations, which in content is analogous to basic (radical) innovation and are carry a few, but noticeable consumer improvements.Such a catchingup policy is typical for markets of monopolistic competition [2].

The Theory of innovations by J. Schumpeter was worked out and augmented by a number of his followers - «neo-Schumpeterians», such as G. Mensh, A. Klyankhkneht and Y. van Dein.

G. Mensh, like J. Schumpeter, explored the dynamics of economic growth based on the theory of long-term Kondratievwaves and connected the cyclical development with the emerge of basic innovations, which have an exhaustive potential. According to G. Mensh, the situation, when the basic innovations exhaust their capabilities, is called the "technological draw", in this case, the economy goes to a depressive state [12].

This situation is explained by the emergence of radical basic innovations leads, in turn, to the emergence of a large number of new enterprises with interconnected development cycles and modifies market infrastructure.

First, the demand for new products will significantly exceed the offer, what will be accomplished by the high rate of economic growth, and the high rate of profits will stimulate the transfusion of capital from other industries, new enterprises will enter the market; in course of time, basis innovations will exhaust its potential, and firms, in order to preserve high profit margin, in terms of competitive market (monopolistic competition) will improve products, without affecting its functional characteristics (such innovations were called "improving innovations", or "innovationprocess") [11]; at high prices and a large number of competitors, the demand for products will be less than the supply. This situation would force the company to enter unexplored international markets, the rate of return on investment will subside, which will lead to a significant transfer of capital to financial markets.

Anyway, speculative transactions at the financial markets will reach huge turnover and, as the result, profits compared to the real sector will fall, what will signal the readiness of production to receive investment.

In another scenario, speculative operations will be completed by the financial crisis and recession, when the new wave and growth phase begin. G. Mensh believed, that economy becomes structurally ready to large-scale innovations-products in the stage of depression; at this stage, clusters of innovations are being formed, and they will have an embodiment as new wave products [10].

The scientist associates discrete nature of producing basic innovations with market mechanism particular qualities of functioning and its inherent contradictions, such as: low sensitivity to reorientation of the functioning of companies in the "old" areas and their transition to "new", more risky areas; contradictions between short-term goals, aimed at maximizing profits, and long-term objectives that are essential for new innovations; minimization of innovation costs; contradictions of communication "principal - agent - engineer", which shows a controversy of goals and diametrically opposite understanding of behavior and strategy of a company.

According to G. Mensh, GDP dynamics is S-logistic curve shaped, correlated with long waves phases and appears as a life-cycle indicator of production technology. At the final stage of the old technological method, old curve smoothly changes into a new one; the imposition of S-logistic curves causes instability, which is the "technological draw" [12].

The economic cycles analysis is also devoted to Y. van Dein, who investigated the theory of long waves and its "Schumpeter" interpretation. Recognizing the importance of the impact of technological innovation on economic development and their dependence on business activity, the scientist has identified three components of the innovation process: technological innovations; life cycle of innovations; market infrastructure [16].

Y. van Dein, similarly to G. Mensh and K. Freeman, highlighted the "innovations-products" 
and "innovations-processes", emphasized on the importance of restructuring the market's infrastructure and stimulating investments, in order to uniform the innovation processes in time. But the study of circularity of the innovative processes of scientists did not find empirical confirmation.

Based on the achievement of «neoSchumpeterians» predecessors in the research of the innovative processes of long waves, A. Klyankhkneht qualitatively expanded the concept of innovations, complementing it with a factor of risk: in the phase of a recession of a long wave, new clusters of radical innovations appear, these clusters can replace the existing technological production method and significantly affect the preferences of consumers in future. This phenomenon is directly related to the increasing tendency to invest and reducing the risk of losing profitability by companies, because entrepreneurs "have nothing to lose"in the stage of production decline.

On the other hand, in the phase of growth of consumer demand, stimulated by radical innovations, and, consequently, profitability standards, entrepreneurs are restrained from risky investment decisions in the field of innovation, therefore, firms prefer to improve the technical characteristics of existing products, without affecting the content of the product significantly.

Although, A. Klyankhkneht has also noticed, that the period of producing radical innovations tends to continue at the initial stage of the long wave lifting phase, i.e. high concentration of innovations promotes prolongation of the innovation period [9].

Researches of K. Freeman, D. Clark and L. Suyte were an important and logical stage of development of science of innovations in the context of international cooperation [6].

K. Freeman and his followers, in contrast to «neoSchumpeterians», introduced the concept of technological system, which is a set of interrelated technological and social innovations. The scientists also investigate the life cycle of innovations and associate it with diffusion, i.e. the ability to spread in space-time. Dynamics and uneven dissemination of innovations is observed in this case: the emergence of innovations in certain areas stimulates economic growth and acceleration of production. Further diffusion will facilitate the establishment of unified technological system in a country.

However, the further spatial expansion of innovation, as a rule, takes place at the stage of maturity of the technological system, that is, the flowering of technological systems in some countries will be accompanied by ageing of these systems in their countries of origin. This explains the uneven development, lags, and exhaustive possibilities of cooperation between countries with different levels of technical readiness. The transition to a new technological conclusion is impossible without reidentification and revision of the basic provisions of the determinants and components of the system, relations between them and the system as a whole.

This process was determined as a change in the technological paradigm and was detailed by
K. Freeman: "Technical and economic paradigm is a concentration of interrelated technical organizational and managerial innovations, the advantages of which to look for not only in a new range of products and systems, but most of all in the dynamics of relative structure of costs for all possible investments in production. Each new paradigm has a particular attachment, that can be called a "key factor" of this paradigm, characterized by falling relative expenses and universal availability. The modern paradigm shift can be seen as a transition from a technology, «based on a cheap energy», to a technology, "based mostly on cheap attachments of information, borrowed from microelectronics success and telecommunications technology» [5].

As can be seen from the definition, the analysis of paradigm shifts and innovative transformations led the researcher to an audit of the cost category: the value of innovations depends on is their ability to minimize production costs in the long-term perspective.

There is a significant difference between «neoSchumpeterians» and K. Freeman and their views: Freeman believed that the base technology cluster is formed not in the recession phase, but in the lifting phase (ascending segment): during the period of rising of employment, prices and volume of costs. Enterprises, expecting further growth of production, will invest into fundamental development (induced investment), which will contribute to the innovation cluster formation and to a new technological system in future.

M. Castels, famous technocrat researcher, highlighted such features of the modern sociotechnical paradigm of the global techno-innovation system [8]: information is a new system material; technologies affect information, not vice versa, which has been a characteristic of the previous STR; an embodiment of the new paradigm has a comprehensive effect, because the integral impact of information on the collective and individual consciousness (and consequently, their activity) spreads the paradigm on all aspects of the system functioning; the presence of network logic as a set of relations based on information technology; network morphology easily adapts to the complexity of interactions and unpredictable development models arising from the creative power of these interactions; network logic is designed to structure something unstructured, keeping itself elastic, as unstructured elements are main attractors of development; the technological paradigm is based on elasticity; ability of the system to reconfiguration; growing technology convergence in highly integrated system, and outdated technological trajectories of development are not different among themselves.

In contrast to the systemic approach of K. Freeman in 1980-ies of the University of Santa Fe (New Mexico, USA) formed a union of scientists whose views are brought together relevant theory of chaos and bifurcations; the scientists formulated their joint, epistemological approach, which was identified by analysts as "complexity". The main attention was paid to the conditions of self-forming structures, which create complexity from the elementary, the highest 
order from chaos through several levels of interactivity after the formation of the basic structures. The problem of the method is to prevent the construction of integration, structuring frameworks and strong random and functional relations, so the concept of scientists can be understood as a way of thinking about the diverse and ambiguous, both society and the technological system in general; It is the epistemological value of the method [13].

Conclusion.

The primary conclusion of the research is the urgency to create a strong national innovation system in Ukraine, considering the specificity of those elements that are now the basis of functioning of innovative systems. It is very important to detect the innovative boom and react to newly created inventions with improving innovations in time, at the stage of the origin of new innovation system. Another important conclusion is to understand economic relations of the global network system. The fastest access of domestic enterprises to world network markets not only to develop the sales network, but also to search for innovative solutions and creative interactions. These practices are suitable for most countries, which have adopted the experience of world's innovative leaders and now are competitive players of the world market of high technologies.

\section{РОЗВИТОК ТЕОРІЇ ІННОВАЦІЙ В КОНТЕКСТІ НОВОЇ ПРОМИСЛОВОЇ РЕВОЛЮЦІЇ}

Довгаль Олена Андріївна, докт. екон. наук., професор, Харківський національний університет імені В. Н. Каразіна, м. Свободи, 6, м. Харків, Україна, 61022, e-mail: e.dovgal@karazin.ua; ORCID: https://orcid.org/0000-0003-3219-9731

Махова Лілія Володимирівна, аспірант Харківський національний університет імені В. Н. Каразіна, м. Свободи, 6, м. Харків, Україна, 61022, e-mail: makhova@karazin.ua

Актуальність дослідження обумовлена тим, що значне збільшення частки наукоємкого виробництва в сукупному продукті світового господарства як наслідок нової промислової революції середини XX - початку XXI ст. визначає абсолютно новий із погляду світового досвіду спектр системи поглядів на світову економічну систему в цілому. Предметом дослідження в статті є процес розвитку теорії інноваційної системи, аналіз впливу теорії «довгих хвиль» на інноваційний розвиток суспільства. Мета аналіз розвитку теорії глобальної та національної інноваційних високотехнологічних систем у часі з урахуванням гіпотези існування жорсткого зв'язку між довгими хвилями та періодами виникнення базових інновацій на різних фразах хвиль із метою усвідомлення можливих варіантів розвитку подій та формування відповідної реакції для забезпечення безперебійного процесу функціонування національної інноваційної системи у контексті нової промислової революції. Завданнями дослідження є визначення закономірностей життєвого циклу інновацій та їх дифузії для виявлення переваг та недоліків трансферу високотехнологічних продуктів для національної інноваційної системи, а також тенденцій розвитку та нових чинників, які в умовах нової промислової революції визначають сутність сучасної ефективної високотехнологічної системи. Використовуються загальнонаукові методи: системний аналіз - для визначення закономірностей життєвого циклу інновацій та їх дифузії для виявлення переваг та недоліків трансферу високотехнологічних продуктів для національної інноваційної системи, фракторний аналіз - для формалізації причинно-наслідкових взаємозв'язків досліджуваних факторів розвитку сучасної ефективної високотехнологічної системи. Отримано такі результати: на основі проведеного аналізу впливу теорії «довгих хвиль» на інноваційний розвиток суспільства доведено необхідність якнайшвидшого виходу на світові мережеві ринки вітчизняних підприємств із метою не лише освоєння збутової мережі, а й пошуку інноваційних рішень та творчих взаємодій. Згадані практики $€$ адекватними для більшості країн, що перейняли досвід світових інноваційних лідерів і нині $€$ конкурентоздатними акторами світового ринку високих технологій. Висновки: нагальність створення потужної національної інноваційної системи в Україні з урахуванням специфіки тих елементів інноваційних систем, що нині $є$ основою їх функціонування.

Ключові слова: інновації, інноваційний розвиток, глобальні виклики, національна конкурентоспроможність, інноваційний потенціал, нова промислова революція.

\section{РАЗВИТИЕ ТЕОРИИ ИННОВАЦИЙ В КОНТЕКСТЕ НОВОЙ ПРОМЫШЛЕННОЙ РЕВОЛЮЦИИ}

Довгаль Елена Андреевна, докт. экон. наук, профессор, Харьковский национальный университет имени В. Н. Каразина, пл. Свободы, 6, г. Харьков, Украина, 61022, e-mail: e.dovgal@karazin.ua; ORCID https://orcid.org/0000-0003-3219-9731

Махова Лилия Владмировна, аспирант, Харьковский национальный университет имени В. Н. Каразина, пл. Свободы, 6, г. Харьков, Украина, 61022, e-mail: makhova@karazin.ua

Актуальность исследования обусловлена тем, что значительное увеличение доли наукоемкого производства в совокупном продукте мирового хозяйства как следствие новой промышленной революции середины XX - начала XXI в. определяет совершенно новый с точки зрения мирового опыта спектр системы взглядов на мировую экономическую систему в целом. Предметом исследования в статье является процесс развития теории инновационной системы, анализ влияния теории «длинных волн» на инновационное развитие общества. Цель - анализ развития теории глобальной и национальной инновационных высокотехнологичных систем во времени с учетом гипотезы существования жесткой связи между длинными волнами и периодами возникновения базовых инноваций на разных фазах волн с целью осознания возможных вариантов развития событий и фрормирования ответной реакции для обеспечения бесперебойного процесса функционирования национальной инновационной системы в контексте новой промышленной революции. Задачами исследования является определение закономерностей жизненного цикла инноваций и их диффузии для выявления преимуществ и недостатков трансфера высокотехнологичных продуктов для национальной инновационной системы, а также тенденций развития и новых факторов, которые в условиях новой промышленной революции определяют сущность современной эффективной высокотехнологичной системы. Используются общенаучные методы: системный анализ - для определения закономерностей жизненного цикла инноваций и их диффузии для выявления преимуществ и недостатков трансфера высокотехнологичных продуктов для национальной инновационной системы, факторный анализ - для формализации причинно-следственных взаимосвязей исследуемых факторов развития современной эффективной высокотехнологичной системы. Получены следующие результаты: на основе проведенного анализа влияния теории «длинных волн» на инновационное развитие общества доказана необходимость скорейшего выхода на мировые сетевые рынки отечественных предприятий с целью не только освоение сбытовой сети, но и поиска инновационных решений и творческих взаимодействий. Упомянутые практики являются адекватными для большинства стран переняли опыт мировых инновационных лидеров и сейчас являются конкурентоспособными актерами мирового рынка высоких технологий. Выводы: необходимости создания мощной 
национальной инновационной системы в Украине с учетом специфики тех элементов инновационных систем, в настоящее время является основой их функционирования.

Ключевые слова: инновации, инновационное развитие, глобальные вызовы, национальная конкурентоспособность, инновационный потенциал, новая промышленная революция.

\section{References}

1. Babenko, V., Boichenko, O., Koniaieva, Y. (2019). Efficiency of Human Resource Management in Industrial Automation Enterprises with Prospects of Innovative Susceptibility. Advances in Economics, Business and Management Research. 6th International Conference on Strategies, Models and Technologies of Economic Systems Management (SMTESM 2019). Atlantis Press, vol. 95, 119-124. doi: https://doi.org/10.2991/smtesm-19.2019.24

2. Breznitz D. (2007). Innovation and the State : Political Choice and Strategies for Growth in Israel, Taiwan, and Ireland. New Haven and London, Yale University Press.

3. Danyliuk, M., Babenko, V., Krykhivska, N., Oryshchyn, T. (2019). Forming an Innovative Exopreneurship Model to Achieve Strategic Goals. Advances in Economics, Business and Management Research, Proceedings of the 2019 7th International Conference on Modeling, Development and Strategic Management of Economic System (MDSMES 2019), vol. 99. doi: https://doi.org/10.2991/mdsmes-19.2019.16

4. Dovgal O., Dovgal G. (2017). Hlobalnyi innovatsiinyi prostir: peredumovy, spetsyfika ta instrumenty formuvannia [Global Innovation Space: Prerequisites, Specifics and Tools of Formation], Problems of Economy. 1, 15-20. Available at: https://www.problecon.com/export_pdf/problems-of-economy-2017-1_0-pages-15_20.pdf (in Ukrainian)

5. Freeman C. (1987). Technical Innovation, Diffusion and Long Cycles of Economic Development The LongWave Debate. Berlin.

6. Freeman C., Clark J., Soete L. (1982). Unemployment and Technical Innovation. Study of Long Waves and Economic Development. London : Frances Pinter.

7. Kao J. (2007). Innovation Nation: How America is Losing Its Innovation Edge, Why It Matters, And What We Can Do To Get It Back. N.Y., Free Press.

8. Kastels M. (2000). Informatsionnaya epoha: ekonomika, obschestvo i kultura [Information age: economy, society and culture] / per. s angl. pod nauch. red. O.I. Shkaratana. Moskva : GU VShE (in Russian).

9. Kleinkneht A. (1987). Innovation Patterns in Crisis and Prosperity: Schumpeter's Long Cycle Reconsidered. London : Macmillan.

10. Mensh G. (1971). O dinamike tehnicheskogo progressa [On the dynamics of technical progress]. Zhurnal ekonomiki predpriyatiya, 41, 295-314. (in Russian)

11. Mensh G. (1972). Bazisnyie innovatsii i innovatsii sovershenstvovaniya [Basic innovations and innovations of improvement]. Zhurnal ekonomiki predpriyatiya, 42, 291 - 297. (in Russian)

12. Mensh G. (1979). Stalemate in Technology: Innovation Overcome the Depression. Cambridge : Mass.

13. Ramazanov, S., Antoshkina, L., Babenko, V., Akhmedov, R. Integrated model of stochastic dynamics for control of a socio-ecological-oriented innovation economy (2019). Periodicals of Engineering and Natural Sciences, vol. 7 , no. 2, pp. 763-773. doi: http://dx.doi.org/10.21533/pen.v7i2.557 Available at: http://pen.ius.edu.ba/index.php/pen/article/view/557

14. Santa Fe Institute. URL: http://www.santafe.edu

15. Schumpeter J. (1939). Bussiness Cycle. A Theoretical, Historical and Statistical Analysis of Capitalist Process. New York : MacGraw-Hill.

16. Van Duijn J.J. (1983).The Long Wave in Economic Life. London.

\section{Література}

1. Babenko, V., Boichenko, O., Koniaieva, Y. Efficiency of Human Resource Management in Industrial Automation Enterprises with Prospects of Innovative Susceptibility. Advances in Economics, Business and Management Research. 6th International Conference on Strategies, Models and Technologies of Economic Systems Management (SMTESM 2019). Atlantis Press, 2019, vol. 95, 119-124. doi: https://doi.org/10.2991/smtesm-19.2019.24

2. Breznitz D. Innovation and the State : Political Choice and Strategies for Growth in Israel, Taiwan, and Ireland. New Haven and London, Yale University Press, 2007.

3. Danyliuk, M., Babenko, V., Krykhivska, N., Oryshchyn, T. Forming an Innovative Exopreneurship Model to Achieve Strategic Goals. Advances in Economics, Business and Management Research, Proceedings of the 2019 7th International Conference on Modeling, Development and Strategic Management of Economic System (MDSMES 2019), 2019, vol. 99. doi: https://doi.org/10.2991/mdsmes-19.2019.16

4. Dovgal O., Dovgal G. Глобальний інноваційний простір: передумови, специфіка та інструменти формування. Проблеми економіки. 2017. № 1. C. 15-20. URL: https://www.problecon.com/export_pdf/problems-ofeconomy-2017-1_0-pages-15_20.pdf (in Ukrainian)

5. Freeman C. Technical Innovation, Diffusion and Long Cycles of Economic Development The Long-Wave Debate. Berlin, 1987

6. Freeman C., Clark J., Soete L. Unemployment and Technical Innovation. Study of Long Waves and Economic Development. London : Frances Pinter, 1982.

7. Kao J. Innovation Nation: How America is Losing Its Innovation Edge, Why It Matters, And What We Can Do To Get It Back. N.Y., Free Press, 2007.

8. Кастельс М. Информационная эпоха: экономика, общество и культура / пер. с англ. под науч. ред. О.И. Шкаратана. М. :ГУ ВШЭ, 2000. 
9. Kleinkneht A. Innovation Patterns in Crisis and Prosperity: Schumpeter's Long Cycle Reconsidered. London : Macmillan, 1987.

10. Менш Г. О динамике технического прогресса. Журнал экономики преgприятия. 1971. № 41. С. 295 - 314.

11. Менш Г. Базисные инновации и инновации совершенствования. Журнал экономики преgприятия. 1972. № 42. C. $291-297$.

12. Mensh G. Stalemate in Technology: Innovation Overcome the Depression. Cambridge : Mass, 1979.

13. Ramazanov, S., Antoshkina, L., Babenko, V., Akhmedov, R. Integrated model of stochastic dynamics for control of a socio-ecological-oriented innovation economy. Periodicals of Engineering and Natural Sciences, 2019,

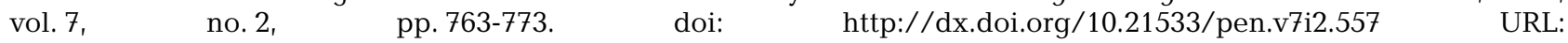
http://pen.ius.edu.ba/index.php/pen/article/view/557

14. Santa Fe Institute. URL: http://www.santafe.edu.

15. Schumpeter J. Bussiness Cycle. A Theoretical, Historical and Statistical Analysis of Capitalist Process. New York : MacGraw-Hill, 1939.

16. Van Duijn J.J. The Long Wave in Economic Life. London, 1983. 